\title{
SODIUM CHLORIDE-INDUCED CONFORMATIONAL CHANGE IN TRNA AS MEASURED BY CIRCULAR DICHROISM
}

\author{
SZYMON SARBAK, MELANIA KUJAWA, HANNA JURGA-NOWAK, ANDRZEJ DOBEK
}

Department of Physics, Adam Mickiewicz University, Umultowska 85, 61-614 Poznań,

Received October 25, 2015; accepted December 21, 2015; published online December 24, 2015

\begin{abstract}
The effect of 0.01-1 M sodium ions on the conformation of the folded brewer's yeast tRNA ${ }^{\text {Phe }}$ was examined by circular dichroism method in the region $200-350 \mathrm{~nm}$. The minimum peak at about $210 \mathrm{~nm}$ for tRNA solution with $50 \mathrm{mM}$ sodium chloride showed a decrease in magnitude by $26-30 \%$ in comparison to that recorded for the solution of higher NaCl content. The depths of the peaks at $225 \mathrm{~nm}$ and $233 \mathrm{~nm}$ for two solutions with the lowest sodium chloride concentrations $\left(\mathbf{c}_{\mathrm{NaCl}}=10 \mathrm{mM}, \mathrm{c}_{\mathrm{NaCl}}=50 \mathrm{mM}\right)$ were changed by $3-10 \%$ relative to the those in the spectra of other samples, for the $260 \mathrm{~nm}$ maximum peak a decrease in height was $21-25 \%$. In the region 300-350 nm no significant difference was observed. The results point to a strong relationship between concentration of sodium ions and stabilization process of secondary and tertiary tRNA structure, which indicates the influence of sodium ions on stacking and base-pairing interactions.
\end{abstract}

\section{INTRODUCTION}

Biological functions of the macromolecules occurring in the living cells are mostly conditioned by their structure and interactions. Present-day research in molecular biology, biochemistry or biophysics is mostly focused on the structure-activity relationship (SAR). Transfer ribonucleic acids (tRNAs) play a vital role in the living organism. They are adaptor molecules with the main function of delivering amino acids to the ribosomes at where the peptide bonds are constructed (in the order specified by mRNA) (Ojala, Merkel, Gelfand \& Attardi, 1980; Westhof, Dumas \& Moras, 1985; Yokoyama, Watanabe, Murao, Ishikura, Yarnaizumi, Nishimura \& Miyazawa, 1985; Kawai G., Ue H., Yasuda M., Sakamato K., Hashizume T. McCloskey JA., Miyazawa T. \& Yokoyama S, 1991). This kind of function is possible due to their highly specific molecular conformation. From all kinds of ribonucleic acids in the cell, $15 \%$ is made by transfer RNAs. For each amino acid in the living organism, there is at least one kind of tRNA (in total there are 31 to 40 types of tRNAs - depending on species) (Alberts, Bray, Hopkin, Johnson, Lewis, Raff, Roberts \& Walter 2009; Turner, McLennan, Bates \& White, 1998). In order to fully understand the biochemical processes taking place on the molecular level in tRNA molecules, it is necessary to examine their physicochemical structure in the crystal state as well as the dependence of this structure on external conditions (e.g. ionic strength, temperature, $\mathrm{pH}$, etc.).
Exposure of the tRNA molecule to salt ions in different concentrations has been proved to cause structural changes (Dobek, Patkowski, Labuda, \& Augustyniak, 1975; Dobek, Patkowski \& Labuda, 1977; Labuda, Ahertle \& Augustyniak, 1977; Adams, Lindahl \& Fresco, 1967; Dudock, DiPeri \& Michael, 1970; Kay \& Willick, 1971; Ishida \& Sueoka, 1968). The characteristic and complicated structure of tRNA, both secondary (resembling clover leaf) and tertiary (resembling letter L) is a sensitive indicator of even slightest changes in ionic environment (Kay et al., 1971; Ishida et al., 1968; Cantor, Jaskunas \& Tinoco, 1966; Doctor, Fuller \& Webb, 1969). Literature provides reports that reveal different types of interaction of monovalent and bivalent ions with transfer ribonucleic acids. It has been documented that different character of $\mathrm{Mg}^{2+}$ binding to tRNA depends upon the initial conformation of the molecule (Labuda et al. 1977). In NaCl-free solution, there are two types of tRNA interaction with $\mathrm{Mg}^{2+}$, a strong one characterized by a binding constant $\mathrm{K}_{\mathrm{s}}=1.5 \times 10^{5}$ $\left[\mathrm{M}^{-1}\right], \mathrm{n}=2.4 \mathrm{Mg}^{2+} /$ molecule and a weak independent binding, $\mathrm{K}_{\mathrm{w}}=9 * 10^{3}\left[\mathrm{M}^{-1}\right]$. In $0.1 \mathrm{M} \mathrm{NaCl}$ solution the two independent types of interaction are weak, since $\mathrm{Na}^{+}$is known to be a competitive inhibitor of $\mathrm{Mg}^{2+}$ binding. When $\mathrm{NaCl}$ concentration increases, then $2 \mathrm{Na}^{+} / \mathrm{Mg}^{2+}$ binding site is found to be formed and it has been observed that $\mathrm{Na}^{+}$destabilizes the tRNA conformation induced by low concentration of $\mathrm{Mg}^{2+}$ ions. The results of EPR and NMR (Cohn, Danchin \& Grunberg-Manago, 1969; Danchin, 1972) measure- 
ments have also exposed two types of binding sites for $\mathrm{Mg}^{2+}$ ions in the tRNA molecule: one is a strong cooperative site characterized by the association constant of $5 \times 10^{5} \mathrm{~mol}^{-1}$, and the other one is weak, characterized by the association constant of $2 \times 10^{3}$ $\mathrm{mol}^{-1}$. Analogical results have been obtained calorimetrically (Rialdi, Levy \& Biltonen, 1972). In the presence of only $\mathrm{Na}^{+}$ions, all binding sites are weak, characterized by the association constant of around $60 \mathrm{~mol}^{-1}$ (Danchin, 1972). Structural changes in tRNA can be well observed by means of the chiral optic methods. Circular Dichroism Spectroscopy (CD) permits detection of the presence of different secondary and tertiary structures in biopolymers (Fresco et al., 1966; Adams et. al, 1967; Ishida et al., 1968; Cantor et. al., 1966). The CD spectrum of tRNA in native conditions is characterized by four peaks, corresponding to the following elements of secondary and tertiary structure: 1) double-stranded helix $-\lambda=210 \mathrm{~nm}$ and $224 \mathrm{~nm}, 2)$ base-stacking $-\lambda=$ $233 \mathrm{~nm}$ and $264 \mathrm{~nm}$ (Basu, Jaisankar \& Kumar, 2013). The spectra acquired from the circular dichroism studies are the source of much important information concerning interactions occurring in the transfer ribonucleic acids solutions (Kelly \& Pric, 2000; Riazance-Lawrence \& Johnson, 1992).

\section{MATERIALS \& METHODS}

The measurements were performed on buffered solutions of mixed tRNA (mainly tRNA $^{\text {Phe }}-$ a phenylalanine specific tRNA) extracted from brewer's yeast, Boehringer Mannheim GmbH. The samples were additionally purified using sizeexclusion chromatography on Sephadex G-100 ${ }^{\circledR}$ $\left(\right.$ Sigma Aldrich $\left.{ }^{\circledR}\right)$ in order to precisely separate the tRNA molecules from the dye used in the cell isolation procedure, along with the other contaminations. All the buffer salts were of analytical grade or higher. Solutions were freshly prepared using the buffer and kept protected in the dark cold store room. All experiments were conducted using 10 $\mathrm{mM}$ Tris buffer of $\mathrm{pH}=6.5$ containing $100 \mathrm{mM} \mathrm{NaCl}$ and $1 \mathrm{mM}$ EDTA prepared in deionized water. The $\mathrm{pH}$ value was adjusted with hydrochloric acid.

\section{SEC Chromatography}

Purification was performed using a chromatographic setup consisting of one-meter-long glass column, packed with Sephadex G-100 ${ }^{\circledR}$ (Sigma Aldrich $^{\circledR}$ ) gel, RediFrac fraction collector and UVmonitor (both from Pharmacia $\mathrm{LKB}^{\circledR}$ ). Absorbances of collected fractions were measured by means of a Hitachi U2800A spectrophotometer.

\section{Dialysis}

After purification, the samples were dialyzed in appropriate buffers, containing Tris(hydroxymethyl) aminomethane, sodium chloride and magnesium chloride in concentrations of: $\mathrm{c}_{\text {Tris }}=10 \mathrm{mM}, \mathrm{c}_{\mathrm{NaCl}}=$ $100 \mathrm{mM}$ and $\mathrm{c}_{\mathrm{MgCl} 2}=5 \mathrm{mM}$, respectively, at $\mathrm{pH}=6.5$. This buffer composition was used in order to obtain stable and the closest to native tRNA molecule structure. Two changes in the buffer with total volume of $5000 \mathrm{~cm}^{3}$ were performed.

\section{Studies}

The CD spectra of tRNA solutions with different contents of salt ions were recorded using a CD JASCO J-815 spectrometer provided with Spectra Manager II software. The $0.5 \mathrm{~mm}$ optical path length cuvette was used. A scan rate of $50 \mathrm{~nm} / \mathrm{min}$, a bandwidth of $1.0 \mathrm{~nm}$ and the wavelength range of 200 - $350 \mathrm{~nm}$ was set for the experiments. All measurements were performed in room temperature $\left(25^{\circ} \mathrm{C}\right)$. Obtained raw data were normalized by dividing through differing in samples tRNA concentrations.

\section{RESULTS \& DISCUSSION}

Six samples with tRNA concentrations in the range of $0.48 \leq \mathrm{c}_{\mathrm{tRNA}} \leq 0.53\left[\mathrm{mg} / \mathrm{cm}^{3}\right]$ were prepared by adding $10 \mu \mathrm{l}$ tRNA solution after dialysis to $140 \mu \mathrm{l}$ of different concentrated $\mathrm{NaCl}$ solution. The samples were subjected to $\mathrm{CD}$ measurements immediately after preparation. Table 1 presents the Absorbance $\left(\mathrm{A}_{260}\right)$, concentrations of tRNA $\left(\mathrm{c}_{\mathrm{tRNA}}\right)$ and molar concentration of sodium chloride in buffer $\left(\mathrm{c}_{\mathrm{NaCl}}\right)$ for each solution. The CD spectra of the samples studied are presented in Fig. 1.

Table 1. Absorbance, tRNA concentration and molar concentration of sodium ions in the samples.

\begin{tabular}{llll}
\hline $\begin{array}{l}\text { Sample } \\
\text { number }\end{array}$ & $\mathrm{A}_{260}$ & $\begin{array}{l}\mathrm{c}_{\mathrm{tRNA}} \\
{\left[\mathrm{mg} / \mathrm{cm}^{3}\right]}\end{array}$ & $\begin{array}{l}\mathrm{c}_{\mathrm{NaCl}} \\
{[\mathrm{mM}]}\end{array}$ \\
\hline 1 & 0.499 & 0.476 & 10 \\
2 & 0.545 & 0.519 & 50 \\
3 & 0.556 & 0.530 & 100 \\
4 & 0.547 & 0.521 & 200 \\
5 & 0.558 & 0.531 & 500 \\
6 & 0.545 & 0.519 & 1000 \\
\hline
\end{tabular}




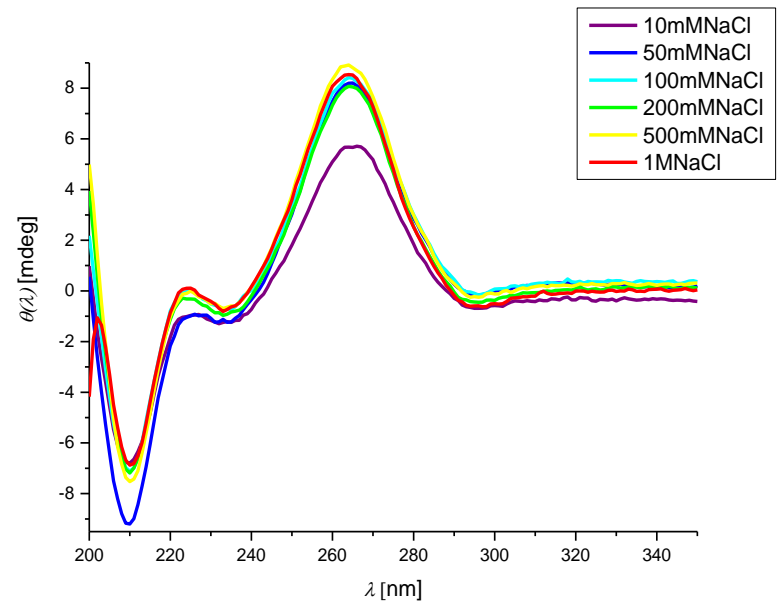

Fig. 1. CD spectra of tRNA samples with different contents of sodium ions $\left(\mathrm{Na}^{+}\right)$.

Different solvent polarity caused by the presence of salt ions led to changes in the spectral band position of molecular absorption of the sample. The values of hypso- and bathochromic shifts occurring in the spectra of each sample are shown in Table 2.

Table 2. Position of characteristic peaks of CD spectra of different tRNA samples.

\begin{tabular}{lllll}
\hline $\begin{array}{l}\mathrm{NaCl} \\
\text { concentration } \\
{[\mathrm{mM}]}\end{array}$ & $\begin{array}{l}\text { Position } \\
\text { of peak } \\
210 \mathrm{~nm} \\
{[\mathrm{~nm}]}\end{array}$ & $\begin{array}{l}\text { Position } \\
\text { of peak } \\
225 \mathrm{~nm} \\
{[\mathrm{~nm}]}\end{array}$ & $\begin{array}{l}\text { Position } \\
\text { of peak } \\
233 \mathrm{~nm} \\
{[\mathrm{~nm}]}\end{array}$ & $\begin{array}{l}\text { Position } \\
\text { of peak } \\
264 \mathrm{~nm} \\
{[\mathrm{~nm}]}\end{array}$ \\
\hline 10 & 210 & 227 & 232 & 266 \\
50 & 210 & 226 & 234 & 265 \\
100 & 210 & 225 & 235 & 264 \\
200 & 210 & 225 & 233 & 264 \\
500 & 210 & 225 & 233 & 264 \\
1000 & 210 & 223 & 233 & 264 \\
\hline
\end{tabular}

The CD signal for the solution with the lowest salt ions content $\left(\mathrm{c}_{\mathrm{NaCl}}=10 \mathrm{mM}\right)$ is significantly lower than those for the other samples (the exact values of CD signal are shown in Table 3) which may indicate not completely formed tertiary tRNA structure.

Table 3. Maximal values of ellipticity for characteristic peaks

\begin{tabular}{lcccc}
\hline $\begin{array}{l}\mathrm{NaCl} \\
\text { concentration } \\
{[\mathrm{mM}]}\end{array}$ & $\begin{array}{c}210 \mathrm{~nm} \\
{[\mathrm{mdeg}]}\end{array}$ & $\begin{array}{c}\text { Wavelength of characteristic peaks } \\
225 \mathrm{~nm} \\
{[\mathrm{mdeg}]}\end{array}$ & $\begin{array}{c}233 \mathrm{~nm} \\
{[\mathrm{mdeg}]}\end{array}$ & $\begin{array}{c}264 \mathrm{~nm} \\
{[\mathrm{mdeg}]}\end{array}$ \\
\hline 10 & -6.800 & -0.933 & -1.296 & 5.675 \\
50 & -9.198 & -0.920 & -1.237 & 8.205 \\
100 & -7.117 & -0.035 & -0.717 & 8.426 \\
200 & -7.188 & -0.286 & -0.965 & 8.074 \\
500 & -7.527 & -0.004 & -0.699 & 8.915 \\
1000 & -6.730 & -0.020 & -0.910 & 8.634 \\
\hline
\end{tabular}

The peaks at $225 \mathrm{~nm}$ corresponding to double-helix structure (Wananu \& Tor, 2012) are deeper for the solutions with two lowest sodium ions concentrations $\left(\mathrm{c}_{\mathrm{NaCl}}=10 \mathrm{mM}\right.$ and $\left.\mathrm{c}_{\mathrm{NaCl}}=50 \mathrm{mM}\right)$. It means that this structure is unstable. For the solution with $\mathrm{c}_{\mathrm{NaCl}}=50$ $\mathrm{mM}$ the depth of the peak at $210 \mathrm{~nm}$ is greater, but considering the decrease in the height of the group of peaks at $225 \mathrm{~nm}-236 \mathrm{~nm}$, it cannot be treated as the most stable environment. The spectra of the solutions of other salt concentrations are almost overlapping each other. The differences in CD signal values are between (0.6 - 0.9) mdeg (Table 3.). Fig 2. shows the normalized spectra $\left(\theta(\lambda) / c_{\text {tRNA }}=f(\lambda)\right)$ in order to check the influence of tRNA concentration on a CD signal.

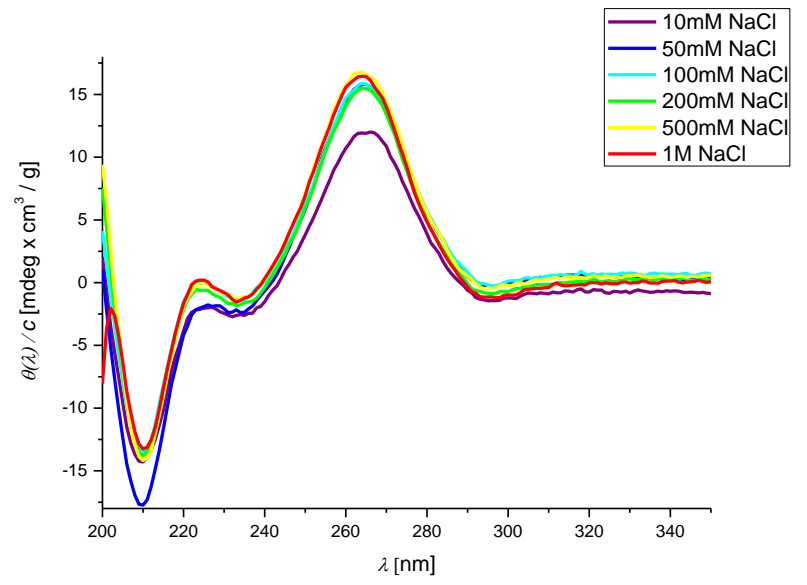

Fig. 2. Normalized CD spectra of tRNA solutions with different $\mathrm{NaCl}$ concentration. 
In tRNA sample studied here the concentration of $\mathrm{Mg}$ ions from dialiysis was amounted to $0.33 \mathrm{mM}$. According to Labuda et.al. 1977, there are three types of $\mathrm{Mg}^{2+}$ binding sites (1, 2 and 3) with affinities toward magnesium ions described by constants $\mathrm{K}_{1}, \mathrm{~K}_{2}, \mathrm{~K}_{3}$, as well as two forms of tRNA molecule in respect to $\mathrm{Mg}^{2+}$ affinities forms $\mathrm{X}_{1}$ and $\mathrm{X}_{1,2,3}$ describing the dependence of $\mathrm{Mg}^{2+}$ binding to tRNA upon $\mathrm{NaCl}$ concentration in the sample. The authors present that $\mathrm{K}_{1} \mathrm{Mg}^{2+}$ binding may be defined as that which makes possible structural arrangement necessary for the appearance of $\mathrm{K}_{2} \mathrm{Mg}^{2+}$ binding sites. Binding to these sites stabilizes the preformed tRNA. Further increase of $\mathrm{Mg}^{2+}$ concentration leads to $\mathrm{K}_{3} \mathrm{Mg}^{2+}$ weak binding sites and has no major conformational effect, but it increases the rigidity of the molecule. The effect of $\mathrm{K}_{1} \mathrm{Mg}^{2+}$ binding may be replaced by binding of $\mathrm{Na}^{+}$in solution containing $1 \mathrm{M}$ $\mathrm{NaCl}$. Increase of $\mathrm{NaCl}$ concentration in solution containing $\mathrm{Mg}^{2+}$ exerts a destabilizing effect on the tRNA molecule lowering its rigidity, this may promote its biological activity.

\section{CONCLUSION}

Analysis of circular dichroism spectra of the tRNA solutions with different sodium ions concentrations revealed a strong positive dependence between the concentration of salt ions and the stabilization process of secondary and tertiary tRNA structures. The character of the CD spectra indicates that the stacking and hydrogen bond interaction between the bases are stronger with increasing $\mathrm{Na}^{+}$contents in tRNA solutions. This effect can be explained by the attachment of sodium ions to phosphate groups resulting in the neutralization of the charge of these groups. In the buffer used in this study tRNA occurs in the native folded form, with two classes of independent $\mathrm{Mg} 2+$ binding sites. After dissolving folded tRNA in $0.01-0.05 \mathrm{M} \mathrm{NaCl}$ solution, the structure resembles that of unfolded tRNA molecule with one class of $\mathrm{Mg}^{2+}$ binding sites. Further results obtained in the presence of $0.1-1 \mathrm{M} \mathrm{NaCl}$ reflect the folded but rigid structure. The $\mathrm{CD}$ spectrum of the solution with the lowest concentration of $\mathrm{NaCl}$ confirms the weakening of stacking and hydrogen bond interactions relative to those occurring in the solutions of higher $\mathrm{NaCl}$ concentrations. These results are in agreement with those of the previous investigation by laser Raman spectroscopy (Dobek et al. 1975) and light scattering measurements (Dobek et al. 1977). After normalization of the $\mathrm{CD}$ spectra in relation to tRNA concentration in the solution, no relevant changes between normalized and non-normalized spectra were observed. There is no significant impact of tRNA molecular concentration in solution on circular dichroism signal in the range of tRNA concentrations studied.

\section{REFERENCES}

Adams A., Lindahl T. \& Fresco J. R.; (1967), Conformational differences between the biologically active and inactive forms of a transfer ribonucleic acid. Proc. Natl. Acad. Sci. USA 57(6), 1684-1691.

Alberts B., Bray D., Hopkin K., Johnson A., Lewis J., Raff M., Roberts K. \& Walter P.; (2014), Essential cell biology, Garland Science Taylor \& Francis Group, 4 ed., 245-250.

Basu A., Jaisankar P., \& Kumar G. S.; (2013), Binding of the 9-O-N-aryl/arylalkyl Amino Carbonyl Methyl Substituted Berberine Analogs to $t R N A^{\text {phe }}$, PloS ONE, 8(3).

Cantor C., Jaskunas S. \& Tinoco Jr. I.; (1966), Optical properties of ribonucleic acids predicted from oligomers, $\mathrm{J}$. Mol. Biol. 20, 39.

Cohn M., Danchin A. \& Grunberg-Manago M.; (1969), Proton Magnetic Relaxation Studies of Manganous Complexes of Transfer RNA and Related Compounds, J. Mol. Biol. 39, 199.

Danchin A.; (1972), tRNA structure and binding sites for cations, Biopolymers 11, 1317.

Dobek A., Patkowski A., Labuda D. \& Augustyniak J.; (1975), Effect of $\mathrm{Na}+$ ion concentration on tRNA conformation in solution studied by laser Raman spectroscopy, J. Raman Spect. 3, 45-54.

Dobek A., Patkowski A. \& Labuda D.; (1977), Light scattering by solutions of tRNA molecules oriented in D.C. magnetic field, J. Polymer Sci. 61(1), 111-121.

Doctor B. P., Fuller W., \& Webb N. L.; (1969), Arrangement of the Helical Regions in E. coli Tyrosine tRNA, Nature (London) 221, 18.

Dudock B. S., DiPeri C. \& Michael M. S.; (1970), Factors determining the specificity of the tRNA aminoacylation reaction: Non-absolute specificity of tRNA-aminoacyl-tRNA synthetase recognition and particular importance of the maximal velocity, J. Biol. Chem. 245, 2465.

Ishida T. \& Sueoka N.; (1968), Tryptophan transfer RNA as the UGA suppressor, J. Biol. Chem. 243, 5329.

Kawai G., Ue H., Yasuda M., Sakamato K., Hashizume T. McCloskey JA., Miyazawa T. \& Yokoyama S. (1991), Nucleic Acids Symp. Ser. 25, 49-50.

Kay C. M. \& Willick G. E.; (1971), Magnesium-induced conformational change in transfer ribonucleic acid as measured by circular dichroism, Biochemistry, 10(12), 2216-2222.

Kelly S. M. \& Pric N. C.; (2000), The Use of Circular Dichroism in the Investigation of Protein Structure and Function, Current Protein and Peptide Science, 1(4), 349384.

Labuda D., Haertle T., \& Augustyniak J.; (1977), Dependence of tRNA Structure in Solution upon Ionic Condition of the Solvent, Eur. J. Biochem. 79, 293-301.

Ojala D., Merkel C., Gelfand R. \& Attardi G.; (1980), The tRNA genes punctuate the reading of genetic information in human mitochondrial DNA, Cell Press 22(2), 393-403.

Rialdi G., Levy J. \& Biltonen R.; (1972), Thermodynamic studies of transfer ribonucleic acids. I. Magnesium binding to yeast phenylalanine transfer ribonucleic acid, Biochemistry 11, 2472. 
Riazance-Lawrence J. H. \& Johnson Jr. W. C.; (1992), Multivalent ions are necessary for poly $[d(A C) \cdot d(G T$ to assume the Z form: A CD study, Biopolymers, 32, 271-276.

Turner P. C., McLennan A.G., Bates A. D. \& White M. R. H.; (1998), Instant notes in molecular biology, ISBN 7-03007305-3. BIOS Scientific Publishers Limited, UK.

Wananu M. \& Tor Y.; (2012), Methods for Studying Nucleic Acid/Drug Interactions, ISBN 978-1-4398-3973-7. CRC Press Taylor \& Francis Group, 1 ed., 52.

Westhof E., Dumas P., \& Moras D.; (1985), Crystallographic refinement of yeast aspartic acid transfer RNA, J. Mol. Biol. 184(1), 119-145.

Yokoyama S., Watanabe T., Murao K., Ishikura H., Yamaizumi Z., Nishimura S. \& Miyazawa T.; (1985), Molecular mechanism of codon recognition by tRNA species with modified uridine in the first position of the anticodon, Proc. Natl. Acad. Sci. USA 82, 4905-4908. 